\title{
Peningkatan Persentase Bobot Karkas Ayam Lokal Pedaging dengan Pemberian Pakan Fermentasi Tepung Kulit Kopi Gayo dan Probiotik di Kabupaten Aceh Tengah
}

\section{Improvement Percentage Weight of Local Chickens Carcass by Feeding Fermented Gayo Coffee Skin Flour and Probiotic in Central Aceh Regency}

\author{
Fita Ridhana ${ }^{1}$, IIma Fitri $^{2}$ \\ ${ }^{1}$ Jurusan Peternakan, Fakultas Pertanian, Universitas Gajah Putih \\ 2Jurusan Agribisnis, Fakultas Pertanian, Universitas Gajah Putih \\ Alamat \\ E-mail: fitaridhana12@gmail.com
}

Sejarah artikel : Menerima : 08 September 2019 Revisi : 16 Oktober 2019 Diterima : 28 Oktober 2019 Online : 10 Desember 2019

\begin{abstract}
ABSTRAK
Tujuan penelitian ini adalah untuk mengetahui pengaruh pemberian pakan fermentasi tepung kulit kopi gayo dengan penambahan probiotik terhadap peningkatan persentase bobot karkas ayam lokal pedaging. Penelitian dilakukan di Takengon, Kabupaten Aceh Tengah pada bulan Juni-September 2019. Penelitian menggunakan 64 ekor ayam lokal pedaging dan menggunakan Rancangan Acak Lengkap (RAL) dengan 4 perlakuan dan 4 ulangan yaitu pemberian rasum fermentasi $0 \%(A), 5 \%(B)$, $10 \%$ (C), dan 15\% (D). Parameter yang diamati meliputi berat badan akhir, pertambahan berat badan $(P B B)$, persentase karkas, lemak abdomen, dan konversi pakan. Data yang diperoleh dianalisis menggunakan ANAVA dan dilakukan uji Duncan apabila data yang diperoleh berbeda nyata. Hasil penelitian menunjukkan bahwa pemberian tepung kulit kopi fermentasi dan probiotik dapat meningkatkan berat badan ayam lokal pedaging dan bobot karkas ayam, akan tetapi tidak berpengaruh terhadap lemak abdomen dan konversi pakan. Pemberian pakan fermentasi tepung kulit kopi 5\% dapat meningkatkan pertambahan berat badan hingga $81,57 \mathrm{gr} / \mathrm{minggu}$ dan bobot karkas ayam hingga $73,29 \%$.
\end{abstract}

Kata Kunci: fermentasi, kulit kopi, probiotik, karkas

\begin{abstract}
A research which aim to determine the effect of gayo coffee skin flour fermentation diet and probiotics on overview improving the percentage carcass of local chickens has been conducted in Takengon, Central Aceh Regency from June until September 2019. The study used 64 local meat chickens and designed by complete randomized consisting of 4 treatments and 4 replications. The treatment of fermentation diet were: $0 \%(A), 5 \%(B), 10 \%(C)$, and 15\% (D). Parameters observed were achievement of final weight, weight gain, percentage of carcass weight, abdominal fat, and feed conversion. Data was analyzed by analysis of variance (ANAVA) and continued by Duncan Multiple Range Test if significant effect was observed. The result showed that feeding of gayo coffee skin flour fermented diet and probiotics improved weight gain and percentage of carcass weight but has no effect on abdominal fat and feed conversion. Feeding 5\% of gayo coffee skin flour fermented diet increased the weight gain up to $81.57 \mathrm{gram} /$ weeks and increased the percentage of chicken carcass weight up to $73,29 \%$.
\end{abstract}

Key word: fermentation, coffee skin flour, porbiotic, carcass

\section{PENDAHULUAN}

Daging merupakan salah satu bahan pangan asal ternak yang dibutuhkan untuk memenuhi kebutuhan protein hewani karena mengandung protein bermutu tinggi dan dapat

memenuhi kebutuhan nutrisi yang diperlukan tubuh. Peningkatan permintaan masyarakat terhadap ayam dan juga mahalnya biaya pakan, sehingga perlu diupayakan 
pemanfaatan limbah pertanian sebagai alternatif bahan pakan ternak untuk memenuhi kebutuhan gizinya.

Ayam lokal pedaging merupakan turunan panjang dari proses sejarah perkembangan genetik perunggasan di tanah air. Ayam lokal pedaging diindikasikan dari hasil domestikasi ayam hutan merah atau red jungle fowls (Gallus gallus) dan ayam hutan hijau atau green jungle fowls (Gallus varius). Awalnya, ayam tersebut hidup di hutan, kemudian didomestikasi serta dikembangkan oleh masyarakat pedesaan (Yaman, 2013). Namun demikian, semenjak dilakukan program pengembangan, pemurnian dan pemuliaan beberapa ayam lokal unggul, saat ini dikenal pula beberapa ras unggul ayam kampung. Ayam lokal pedaging unggul merupakan nama yang dipopulerkan untuk membedakan ayam kampung pedaging lokal, ayam ras pedaging (broiler), dan ayam-ayam hasil cross breeding lain yang menggunakan ayam kampung sebagai pejantan maupun induk. (Yaman, 2013).

Di Kabupaten Aceh Tengah, Kopi Arabika (Coffea Arabica L) merupakan salah satu komoditi pertanian andalan. Buah kopi secara fisik terdiri dari biji, kulit tanduk dengan proporsi $51,59 \%$ sedangkan kulit dan daging proporsinya $48,41 \%$, sehingga sangat baik dimanfaatkan sebagai kosentrat bagi ternak. Hasil analisis proksimat menunjukkan bahwa kandungan nutrisi kulit kopi adalah mengandung 95,22\% bahan kering; 10,47\% protein kasar; 0,26\% lemak; 32,26\% serat kasar; dan mengandung energi (GE) sebanyak $4140 \mathrm{kkal} / \mathrm{kg}$ (Purwadaria et al, 1993). Dilaporkan juga oleh Mastika (2011) bahwa melalui proses fermentasi, ternyata kandungan nutrisi kulit kopi meningkat, yaitu protein kasar menjadi 17,88\%; kecernaan bahan kering meningkat dari $40 \%$ menjadi $50 \%$. Melalui fermentasi dapat menyebabkan struktur dinding sel kulit kopi menjadi padat dan tidak berdebu, sehingga lebih mudah untuk dikonsumsi oleh ternak. Rathinavelu dan Graziosi (2005) menyatakan bahwa limbah kulit buah kopi dapat menggantikan $20 \%$ kebutuhan konsentrat komersial yang digunakan sebagai pakan ternak, dan menekan biaya pakan hingga 30\%.

Hasil limbah industri mengandung protein rendah dan serat kasar yang tinggi sehingga kurang efektif jika diberikan langsung ke ternak unggas. Fermentasi merupakan slah satu cara mengolah bahan pakan secara biologis melibatkan aktifitas mikroorganisme untuk memperbaiki nilai kandungan gizi bahan pakan yang memiliki kualitas rendah. Dilaporkan oleh Bidura (2007) bahwa penggunaan produk fermentasi dalam ransum secara nyata dapat meningkatkan kuantitas dan kualitas karkas, serta menurunkan jumlah lemak abdomen ayam. Fermentasi dapat meningkatkan kualitas nutrisi bahan pakan, karena pada proses fermentasi terjadi perubahan kimiawi senyawasenyawa organik (karbohidrat, lemak, protein, serat kasar) dan bahan organik lain baik dalam keadaan aerob maupun anaerob, melalui kerja enzim yang dihasilkan mikroba. Menurut Umiyasih et al (2008) bahwa peningkatan kualitas nutrisi pada kulit kopi melalui pengecilan partikel dan fermentasi secara nyata dapat meningkatkan protein kasar, menurunkan serat kasar dan TDN. Untuk menjamin ketersediaan bahan pakan asal limbah pertanian dan perkebunan yang melimpah pada musim tertentu, serta mengantisipasi kurangnya hijauan pakan sepanjang tahun maka diperlukan adanya suatu pengolahan atau teknik penyimpanan bahan pakan asal limbah pertanian/ perkebunan. Tujuan penelitian ini adalah untuk mengetahui pengaruh pemberian pakan fermentasi tepung kulit kopi gayo dengan penambahan probiotik terhadap peningkatan persentase bobot karkas ayam lokal pedaging dan mengetahui berapa persentase optimal dari pemberian pakan fermentasi tepung kulit kopi gayo dalam meningkatkan persentase bobot karkas ayam lokal pedaging. Berdasarkan permasalahan diatas, maka diperlukan upaya pemanfaatan limbah hasil pertanian sebagai pakan ternak unggas yang difermentasi serta penambahan probiotik pada ransum untuk meningkatkan pertumbuhan, performa dan persentase bobot karkas ayam.

\section{METODE PENELITIAN Jenis dan Rancangan Penelitian}

Rancangan penelitian yang digunakan adalah menggunakan Rancangan Acak Lengkap (RAL) dengan 4 perlakuan penggunaan ransum fermentasi dan probiotik. Terdapat 4 perlakuan dan setiap perlakuan dilakukan pengulangan sebanyak 4 kali. Setiap kelompok percobaan terdiri dari 4 ekor ayam sehingga total 64 ekor ayam. Bagan penelitian terdapat pada Tabel 1.

Tabel 1. Bagan Perlakuan padda Penelitian

\begin{tabular}{ccccc}
\hline Ulangan & \multicolumn{4}{c}{ Persentase ransum fermentasi } \\
\cline { 2 - 5 }$(\mathrm{n})$ & $\mathrm{A}=0 \%$ & $\mathrm{~B}=5 \%$ & $\mathrm{C}=10 \%$ & $\mathrm{D}=15 \%$ \\
\hline 1 & $\mathrm{~A} 1$ & $\mathrm{~B} 1$ & $\mathrm{C} 1$ & $\mathrm{D} 1$ \\
2 & $\mathrm{~A} 2$ & $\mathrm{~B} 2$ & $\mathrm{C} 2$ & $\mathrm{D} 2$ \\
3 & $\mathrm{~A} 3$ & $\mathrm{~B} 3$ & $\mathrm{C} 3$ & $\mathrm{D} 3$ \\
4 & $\mathrm{~A} 4$ & $\mathrm{~B} 4$ & $\mathrm{C} 4$ & $\mathrm{D} 4$ \\
\hline Total & 16 & 16 & 16 & 16 \\
\hline
\end{tabular}

Keterangan:

$\mathrm{A}, \mathrm{B}, \mathrm{C}, \mathrm{D}=$ Perlakuan ransum penelitian

1-4 = Ulangan Penelitian 
$0 \%-30 \%=$ Perlakuan pemberian pakan fermentasi A1-D4 = Unit percobaan

Perlakuan penggunaan probiotik dan pakan fermentasi dengan taraf yang berbeda seperti ditunjukkan pada Tabel 2, yaitu:

Tabel 2. Susunan ransum penelitian (\%)

\begin{tabular}{|c|c|c|c|c|}
\hline \multirow{3}{*}{ Bahan Pakan } & \multicolumn{4}{|c|}{ Ransum Perlakuan (\%) } \\
\hline & $A$ & $\mathrm{~B}$ & C & $\mathrm{D}$ \\
\hline & 0 & 5 & 10 & 15 \\
\hline Pakan & 100 & 94 & 89 & 84 \\
\hline $\begin{array}{l}\text { Pakan } \\
\text { Fermentasi** }\end{array}$ & 0 & 5 & 10 & 15 \\
\hline Probiotik & 0 & 1 & 1 & 1 \\
\hline Total (\%) & 100 & 100 & 100 & 100 \\
\hline Serat Kasar & 5,00 & 5,53 & 6,12 & 6,40 \\
\hline Protein & 20,5 & 19,6 & 18,9 & 18,3 \\
\hline Lemak & 5,00 & 4,94 & 4,94 & 4,93 \\
\hline
\end{tabular}

*N512 (PT. Charoen Phokpan)

**Hasil analisis Lab nutrisi dan makanan ternak Universitas Syiah Kuala

keterangan:

A. Ransum tanpa menggunakan pakan fermentasi dan probiotik

B. Ransum menggunakan pakan fermentasi $5 \%$ dan probiotik $1 \%$

C. Rasum menggunakan pakan fermentasi $10 \%$ dan probiotik $1 \%$

D. Ransum menggunakan pakan fermentasi $15 \%$ dan probiotik $1 \%$

\section{Tempat Dan Waktu Penelitian}

Penelitian ini dilaksanakan di Takengon, Kabupaten Aceh Tengah selama 3 bulan. Tahap pertama yaitu tahap persiapan kandang dan pembuatan ransum fermentasi. Tahap kedua adalah pemeliharaan ayam selama 70 hari serta pengambilan data penelitian. Penelitian ini telah dilaksanakan dari bulan Juni sampai September 2019.

\section{Alat dan Bahan Penelitian}

Alat-alat yang digunakan dalam penelitian ini adalah timbangan analitik, label, tali plastik, buku data dan kamera. Adapun bahan yang digunakan dalam penelitian ini adalah ransum fermentasi yang terdiri dari tepung kulit kopi, tepung jagung dan dedak, ransum komersial yaitu berupa N511 (pakan minggu 1-3) N512 (pakan minggu ke 4 dan seterusnya), probiotik, Vita Chick, multivitamin dan elektrolit sebagai persiapan untuk sistem kekebalan tubuh. Rodalon, larutan antiseptik sebagai pembasmi kuman, bakteri, jamur, dan virus penyebab penyakit pada ternak unggas.
Destan, larutan antiseptik sebagai desinfektan untuk kandang dan peralatan kandang.

\section{Teknik Pengumpulan Data}

Teknik pengambilan sampel penelitian dari 64 ekor ayam diambil 1 ekor dari masingmasing perlakuan berdasarkan penimbangan berat badan rata-rata yang didapat. Sehingga total ayam yang akan digunakan sebagai sampel adalah 16 ekor ayam. Teknik pengambilan sampel dengan cara memotong ayam pada umur 70 hari selanjutnya dilakukan penimbangan pertambahan berat badan, karkas, lemak abdomen, dan perhitungan konversi pakan.

\section{Variabel Penelitian dan Definisi Operasional Variabel}

Variabel penelitian ini terdiri dari variabel bebas, variabel terikat dan variabel kontrol.

a. Variabel terikat dalam penelitian ini adalah pemberin pakan fermentasi dalam berbagai konsentrasi (5\%, $10 \%$ dan $15 \%)$.

b. Variabel bebas dalam penelitian ini adalah berat badan akhir, pertambahan berat badan dan konsumsi pakan

c. Variabel kontrol dalam penelitian ini adalah umur ayam, jenis ayam, pakan komersial, jenis air minum, jumlah pakan, pola pemeliharaan dan teknik pengumpulan data.

\section{Analisis Data}

Data hasil penelitian ini dianalisis menggunakan analisis of variance (ANAVA) untuk mengetahui pengaruh perlakuan terhadap parameter yang diamati. Jika pada analisis ANAVA didapatkan hasil yang berbeda nyata, maka akan dilanjutkan dengan uji Duncan (Steel dan Torrie, 1993).

\section{PEMBAHASAN}

\section{Bobot Badan Akhir dan Pertambahan} Berat Badan

Bobot badan akhir adalah salah satu cara yang digunakan untuk melihat keberhasilan suatu usaha peternakan. Berat badan akhir merupakan penetu harga jual ternak, sehingga mempengaruhi keuntungan yang didapatkan peternak, sedangkan pertambahan berat badan (PBB) merupakan perubahan ukuran berat hidup dan komposisi tubuh. Pertambahan bobot badan dihitung setiap minggu berdasarkan bobot badan sebelumnya dalam satuan gram/minggu/ekor.

Berdasarkan hasil penelitian, pertambahan berat badan, bobot badan akhir, dan konsumsi 
ayam lokal pedaging yang diberi pakan fermentasi tepung kulit kopi dan probiotik dpat dilihat pada Tabel 4.

Tabel 4. Persentase bobot badan akhir, pertambahan berat badan (PBB) dan konsumsi pakan ayam lokal pedaging umr 10 minggu

\begin{tabular}{lcccc}
\hline \multirow{2}{*}{ Variabel } & \multicolumn{4}{c}{ Perlakuan (pakan Fermentasi) } \\
\cline { 2 - 5 } & $\mathrm{A}$ & $\mathrm{B}$ & $\mathrm{C}$ & $\mathrm{D}$ \\
& $(0 \%)$ & $(5 \%)$ & $(10 \%)$ & $(15 \%)$ \\
\hline Berat Badan & $841,25^{\mathrm{a}}$ & $847,5^{\mathrm{a}}$ & $816,46^{\mathrm{b}}$ & $779,25^{\mathrm{c}}$ \\
Akhir (gr/ekor) & $\pm 50,9$ & $\pm 44,4$ & $\pm 80,8$ & $\pm 20,9$ \\
Pertambahan & $80,69^{\mathrm{a}}$ & $81,57^{\mathrm{a}}$ & $78,58^{\mathrm{b}}$ & $74,76^{\mathrm{b}}$ \\
Berat Badan & $\pm 5,1$ & $\pm 4,3$ & $\pm 8,1$ & $\pm 2,1$ \\
\hline gr/ekor/minggu) & $\pm 5,1$ &
\end{tabular}

Keterangan: Superskrip yang berbeda pada baris yang sama menunjukan perbedaan yang nyata $(P<0,05)$.

Hasil analisis ragam pada pemberian pakan fermentasi tepung kulit kopi dan probiotik secara statistik menunjukan perbedaan yang nyata $(P<0,05)$ terhadap berat badan akhir dan pertambahan berat badan. Pada Tabel 4 dapat dilihat perbedaan berat badan akhir tertinggi ayam lokal pedaging terdapat pada perlakuan $\mathrm{B}$ (5\% pakan fermentasi tepung kulit kopi), yaitu dengan rataan 847,5 gr/ekor, dan yang terendah adalah perlakuan D (15\% pakan fermentasi tepung kulit kopi) yaitu dengan rataan 779,25 gr/ekor. Sedangkan hasil pertambahan berat badan berdasarkan hasil analisis ragam pada Tabel 4, pertambahan yang tertinggi adalah pada perlakuan B (5\% pakan fermentasi tepung kulit kopi) PBB mencapai 81,57 gr/ekor/minggu dan yang terendah pada perlakuan D $(15 \%$ pakan fermentasi tepung kuli kopi), PBB mencapai $74,76 \mathrm{gr} / \mathrm{ekor} / \mathrm{ming} g \mathrm{u}$.

Dari hasil penelitian dapat disimpulkan bahwa pemberian pakan fermentasi tepung kulit kopi dapat meningkatkan bobot akhir dan pertambahan berat badan (PBB) ayam lokal pedaging, tanpa meningkatkan jumlah pakan yang dikonsumsi. Sejalan dengan penelitian Intan (2017) yang menyatakan bahwa pemberian limbah tepung kulit kopi terfermentasi $10 \%$ dapat meningkatkan bobot karkas dan performa ayam buras. Demikian pula yang disampaikan Quine R (2014) pemberian tepung kulit kopi dengan konsentrasi $5 \%$ dapat meningkatkan bobot badan dan perumbuhan ayam broiler.

\section{Persentase Karkas}

Berdasarkan hasil penelitian ini, persentase karkas dan lemak abdominal ayam lokal pedaging yang diberikan pakan fermentasi tepung kulit kopi dan probiotik dapat dilihat pada Tabel 5.
Tabel 5. Persentase karkas, lemak abdomen dan konversi pakan ayam lokal pedaging umur 10 minggu.

\begin{tabular}{lllll}
\hline \multirow{2}{*}{ Variabel } & \multicolumn{4}{c}{ Perlakuan (Pakan Fermentasi) } \\
\cline { 2 - 5 } & $\begin{array}{l}\mathrm{A} \\
(0 \%)\end{array}$ & $\begin{array}{l}\mathrm{B} \\
(5 \%)\end{array}$ & $\begin{array}{l}\mathrm{C} \\
(10 \%)\end{array}$ & $\begin{array}{l}\mathrm{D} \\
(15 \%)\end{array}$ \\
\hline $\begin{array}{l}\text { Persentase } \\
\text { bobot }\end{array}$ & $69,59^{\mathrm{a}}$ & $73,29^{\mathrm{b}}$ & $72,46^{\mathrm{b}}$ & $69,81^{\mathrm{a}}$ \\
karkas & $\pm 2,03$ & $\pm 1,63$ & $\pm 1,68$ & $\pm 1,28$ \\
$\begin{array}{l}\text { Persentase } \\
\text { lemak }\end{array}$ & 0,48 & 0,10 & 0,19 & 0,20 \\
abdomen & $\pm 0,23$ & $\pm 0,37$ & $\pm 0,16$ & $\pm 0,22$ \\
Konversi & 3,55 & 3,57 & 3,62 & 3,67 \\
pakan & $\pm 0,12$ & $\pm 0,15$ & $\pm 0,26$ & $\pm 0,26$ \\
\hline Kanany
\end{tabular}

Keterangan: Superskrip yang berbeda pada baris yang sama menunjukan perbedaan yang nyata $(P<0,05)$.

Karkas adalah produk utama dari ayam pedaging, dalam menentukan dan memilih daging lemak abdominal juga termasuk hal yang penting bagi masyarakat selaku konsumen. Bobot karkas ditentukan saat penimbangan ayam yang telah dipotong dan diambil kepala, leher, bulu, kaki, darah dan seluruh isi rongga perut kecuali paru-paru dan ginjal (Yao et al., 2006).

Hasil analisis ragam pada pemberian pakan fermentasi tepung kuli kopi dan probiotik secara statistik menunjukan perbedaan yang nyata $(P<0,05)$ terhadap persentase bobot karkas. Pada Tabel 5 dapat dilihat perbedaan pertambahan persentase bobot karkas tertinggi ayam lokal pedaging terdapat pada perlakuan B (5\% pakan fermentasi), yaitu dengan rataan $73,29 \%$, dan yang terendah adalah perlakuan $\mathrm{A}$ (tanpa pemberian pakan fermentasi) yaitu dengan rataan $69,59 \%$. Meningkatnya persentase bobot karkas disebabkan oleh pakan fermentasi yang mempunyai kandungan nutrisi cukup baik bagi ayam, pakan fermentasi dapat menurunkan serat kasar serta meningkatkan protein kasar akibat dari fungsi probiotik sebagai katalisator dalam pemecahan senyawa-senyawa organik sehingga pakan lebih mudah dicerna (Richana, 2012).

Penelitian Hutabarat (2007) menyatakan pemberian limbah kulit kopi fermentasi dalam pakan ayam buras mampu memacu pertumbuhan komponen karkas ayam (daging dan tulang), hal ini disebabkan oleh peningkatan kualitas protein dari bahan pakan fermentasi oleh tubuh ayam ras pedaging diubah menjadi pertumbuhan daging. Selain itu juga peran probiotik yang menjaga keseimbangan mikrobial di dalam sistem pencernaan ayam dengan cara mempertahankan $\mathrm{pH}$ di dlam saluran pencernaan sehingga meningkatkan 
penyerapan dari makanan yang dikonsumsi (Brady et al., 2000). Dari hasil penelitian dapat disimpulkan bahwa pemberian pakan fermentasi dapat meningkatkan persentase karkas ayam lokal pedaging. Hal ini sejalan dengan dengan penelitian Indarto (2000) menunjukan pemberian subtitusi fermentasi kulit kopi dalam pakan ayam broiler berpengaruh terhadap persentase karkas dan bobot badan dengan kisaran 74,06-79,79\%.

\section{Lemak Abdomen}

Lemak abdominal adalah lemak bagian tubuh yang disimpan dalam rongga perut termasuk lemak yang melindungi bagian gizzard. Tumpukan lemak dalam tubuh ayam termasuk lemak abdomen karena merupakan hasil proses metabolisme zat nutrisi dalam tubuh ayam melebihi tingkat kebutuhan yang diperlukan oleh tubuh ayam itu sendiri, baik sebagai maintenance maupun untuk bereproduksi (Oktaviana et al., 2010). Bagian tubuh yang berperan untuk menyimpan lemak pada ayam adalah perut. Membandingkan bobot lemak abdomen dengan bobot hidup dikalikan 100 adalah cara melihat presentase lemak abdomen (Witantra, 2011).

Hasil analisi ragam pada pemberian pakan fermentasi kulit kopi dan probiotik secara statistik menunjukan perbedaan yang tidak nyata $(P>0,05)$ terhadap persentase lemak abdominal ayam lokal pedaging, hal ini disebabkan karena kandungan energi di dalam ransum yang tidak terlalu berbeda, sehingga tingkat penimbunan energi dalam tubuh dalam bentuk lemak sama antar perlakuan. Berkurangnya nilai energi ransum, atau naiknya persentase protein, akan meningkatkan laju pertumbuhan dan meningkatnya jumlah lemak abdominal karena tingginya kepadatan lemak (Amrullah, 2004).

Berdasarkan Tabel 5, dapat diketahui bahwa persentase lemak abdominal secara berturut turut pada perlakuan $A, B, C$, dan $D$ adalah $A: 0,48, B: 0,10, C: 0,19, D: 0,20$. Dari hasil rataan ini menunjukkan bahwa persentase lemak abdominal kurang dari $1 \%$ dan bila dibandingkan dengan lemak abdomen ayam ras pedaging lainnya ayam lokal pedaging mempunyai lemak abdominal yang lebih rendah.

Menurut Becker et al. (1997) persentase lemak abdominal ayam broiler berkisar antara $0,73 \%$ sampai $3,78 \%$, sedangkan menurut Walad (2007) persentase lemak abdomen ayam kampung berkisar 0,53\% sampai $1,31 \%$. Dilaporkan oleh Bidura (2008) bahwa penggunaan produk fermentasi dalam ransum secara nyata dapat meningkatkan kuantitas dan kualitas karkas, serta menurunkan jumlah lemak abdomen ayam

Haro (2005) menyatakan bahwa lemak dalam tubuh ayam berasal dari pakan dan di hasilkan dari proses sintesis lemak dalam hati . sementara itu mekanisme pembentukan lemak dalam tubuh ayam pedaging dijelaskan oleh Pratikno (2011) bahwa deposisi lemak dalam tubuh ayam pedaging terjadi melalui proses lipogenesis. Hasil uji statistik menunjukkan bahwa persentase lemak abdominal tidak dipengaruhi oleh pemberian tepung kulit kopi fermentasi dengan demikian penambahan tepung kulit kopi fermentasi mampu meningkatkan pertumbuhan bobot badan ayam kampung sehingga menurunkan kadar lemak abdominalnya. Hal yang sama dilaporkan oleh Tillman et al. (1998) bahwa pada umumnya peningkatan bobot badan ayam diikuti oleh menurunnya kandungan lemak abdominal yang menghasilkan produksi daging yang tinggi.

\section{Konversi Pakan}

FCR atau Feed Conversi Ratio adalah perbandingan antara jumlah pakan yang dikonsumsi dengan kanaikan berat badan pada waktu tertentu. Sehingga Rasio Konversi Pakan menunjukan efisiensi penggunaan pakan pada pemeliharaan ayam. Pakan yang diberikan menghasilkan output pertmbahan berat badan yang sesuai dengan standar produksi bibit ayam yang digunakan.

Nilai konversi pakan akan semakin baik jika memiliki nilai yang lebih rendah/ lebih kecil. Data yang diperoleh rata-rata Rasio Konversi Pakan ayam selama pemeliharaan (10 minggu) untuk perlakuan $A, B, C$, dan $D$ adalah 3,55 ; 3,57; 3,62 dan 3,67 (lihat Tabel 5). Dari data hasil penelitian menunjukkan bahwa tidak terjadi perubahan konversi pakan pada keempat perlakuan. Dengan nilai seperti itu maka pakan yang digunakan efisien karena tidak banyak terbuang, sehingga tidak mengakibatkan penurunan berat badannya.

Faktor pemberian pakan, laju perjalanan ransum di dalam saluran pencernaan, $\mathrm{pH}$ saluran pencernaan, mikroba non patogen didalam saluran pencernaan, bentuk ransum, serta komposisi nutrisi ransum juga berperan sangat penting dalam mempengaruhi konversi ransum sebagaimana Lacy dan Vest (2000), menyatakan beberapa faktor utama yang mempengaruhi konversi ransum diantaranya adalah genetik, penyakit, kualitas ransum, sanitasi kandang, temperatur, pengobatan, ventilasi udara, serta managemen kandang. 
Konversi pakan dengan nilai yang tinggi mengindikasikan bahwa efisiensi pemanfaatan pakan tidak begitu baik, sedangkan jika nilai konversinya rendah menunjukan bahwa efisiensi pakan tinggi dan pakan dimanfaatkan baik oleh ternak. Nilai ekonomi dan jumlah pakan juga berkaitan erat dengan nilai FCR pada pemeliharaan ayam pedaging karena jika lebih banyak jumlah pakan akan menurunkan keuntungan yang didapatkan. Dinyatakan pula bahwa produksi yang rendah dan konsumsi pakan yang tinggi adalah penyebab utama nilai FCR ayam pedaging menjadi tinggi.

\section{KESIMPULAN}

Pemberian tepung kulit kopi fermentasi dan probiotik pada pakan ternak dapat meningkatkan persentase karkas ayam lokal pedaging hingga 73,29\%, namun tidak berpengaruh terhadap lemak abdomen dan konversi pakan. Disarankan maksimal pemberian $5 \%$ tepung kulit kopi fermentasi untuk meningkatkan persentase karkas dan bobot badan ayam lokal pedaging.

\section{PUSTAKA}

Amrullah, I. K. (2004). Nutrisi Ayam Broiler. Seri Beternak Mandiri. Lembaga Satu Gunungbudi, Bogor.

Becker WA, Spencer JV, Mirosh LW, Verstrate JA. (1997). Abdominal and carcass fat in five broiler strains. Poult Sci 60(4):693-697.

Bidura, I G. N. G., Candrawati, D.P.M.A., dan Sumardani, N.L.G., (2007). Pengaruh penggunaan daun katuk (Saurupus androgynus) dan daun bawang putih (Allium sativum) dalam ransum terhadap penampilan ayam broiler. Majalah Peternakan, 10: 1-11.

Bidura, I.G. N. G., L. G. Sumardani, T. I. Putri, dan I. B. G. Partama. (2008). Pengaruh Pemberian Ransum Terfermentasi Terhadap Pertambahan Berat Badan, Karkas, dan Jumlah Lemak Abdomen Pada Itik Bali. Jurnal Pengembangan Peternakan Tropis 33 (4) : 274-281.

Brady, L.J., D.D. Gallaher and F.F. Busta. (2000). The role of probiotic cultures in the prevention of colon cancer. J. Nutr. 130: $410 S-414 S$.

Haro C V. (2005). Interaction between dietary polyunsaturated fatty acids and vitamin $E$ in body lipid composition and $\alpha$-tocopherol content of broiler chickens. Thesis. Barcelona, Spain: Universitat Autonoma de.

Hutabarat, 2007. Pengaruh limbah kulit kopi terfermentasi berbeda pada pakan buatan terhadap efisiensi pakan, pertumbuhan ayam buras. Journal of Aquaculture Management and Technology. 2(2): 26-36.

Indarto R.E. (2000). Pengaruh Subtitusi ampas tahu fermentasi dalam pakan berprotein tinggi terhadap performan, kualitas karkas dan perlemakan ayam broiler. Lembaga Penel itian UGM. Yogyakarta.

Lacy, M. dan Vest, L.R. 2000. Improving feed conversion in broiler : a guide for growers.http://www.ces.uga.edu/pubed/c:79 3-W.html. [6 Januari 2007].

Mastika, I M.2011 Potensi Limbah Pertanian dan Industri Pertanian Serta Pemanfatan nya untuk Makan Ternak. Denpasar. 25 September 2011. Pengukuhan Guru Be-sar IImu Makanan Ternak Pada Fakultas Peternakan Universitas Udayana, Denpasar.

Oktaviana D, Zuprizal, Suryanto E. (2010). Pengaruh penambahan ampas virgin coconut oil dalam ransum terhadap performans dan produksi karkas ayam broiler. Bul Peternak. 34:159-164.

Pratikno H. (2011). Lemak abdominal ayam broiler (Gallus sp) karena pengaruh ekstrak kunyit (Curcuma domestica). BIOMA. 13:18.

Purwadaria, T., T. Haryati, T. Setiadi, J. Dharma, A.P. Sinurat dan T. Pasaribu. 1999. Optimalisasi fermentasi (teknologi Bioproses) bungkil kelapa. Kumpulan Hasilhasil Penelitian APBN Tahun Jurnal IImiah IImu-IImu PeternakanAgustus, 2008, Vol. XI. No.3. Pemanfaatan Kapang Aspergillus niger sebagai Inokulan Fermentasi Kulit Kopi dengan Media Cair dan Pengaruhnya terhadap Performans Ayam Broiler 157 Anggaran 1994/1995. Balai Penelitian Ternak Ciawi, Bogor.

Rathinavelu, R. dan G. Graziosi. 2005. Potential Alternative Uses of Coffee Wastes and By-Products. Italia : ICS-UNIDO, Science Park, Department of Biology, University of Trieste, Italy.

Richana, N. (2002). Produksi dan prospek enzim xilanase dalam pengembangan bioindustri di Indonesia, Buletin AgroBio 5 (1): $29-36$

Risa Quine. (2014). Pengaruh Pemberian Tepung Limbah Kulit Kopi sebagai Pakan Tambahan terhadap Pertambahan Bobot Badan Ayam Broiler. Skripsi, Banda Aceh, Universitas Syiah Kuala.

Steel, R.G.D. and ; J.H. Torrie. (1993). Prinsip dan Prosedur Statistika Suatu Pendekatan Biometrik, Jakarta. Terjemahan. P.T. Gramedia.

Tillman, A. D., H. Hartadi, S. Reksohadiprojo, S. Prawirokusumo dan S. Lebdosoekojo. (1998). Ilmu Makanan Ternak Dasar. Gadjah Mada University. Yogyakarta. 
Umiyasih, U dan Y. N. Anggraeny. 2008. Pengaruh Fermentasi Saccharomyces cerevisiae Terhadap Kandungan Nutrisi dan Kecernaan Ampas Pati Aren (Arenga pinnata MERR.).Seminar Nasional Teknologi Peternakan dan Veteriner.

Walad, G.S., (2007). Pengaruh Warna lampu Penerangan terhadap Berat Hidup, Persentase Karkas, Giblet, dan Lemak Abdominal Ayam Broiler. Skripsi. Prodi Teknologi Produksi Ternak., Fakultas Peternakan IPB. Bogor.

Witantra. (2011). Pengaruh Pemberian Lisin dan Metionin Terhadap Persentase Karkas dan Lemak Abdominal pada AyamPedaging Asal Induk Bibit Mudadan Induk Bibit Tua. Artikel IImiah.Universitas Airlangga. Surabaya.

Yaman, M.A. (2013). Ayam Kampung Pedaging Unggul. Penebar Swadaya. Jakarta.

Yao, J., Xiaoyan, T., Haibo, X., Jincheng, H.,. Ming, $X$ and Xiaobing, W., (2006). Effect of choice feeding on performance of gastrointestinal development on feed utilization of broiler. J. Anim. Sci, 19:91-96. 